Research Article

\title{
Role of free radical scavengers in oral malignancies treated with radiotherapy
}

\author{
Virendra Kushwaha ${ }^{1}$, Kamal Sahani ${ }^{2}$, Varun Sharma ${ }^{1,4}{ }^{*}$, Shaheen Saeed ${ }^{1}$, \\ Santosh Kumar Barman ${ }^{3}$
}

\begin{abstract}
${ }^{1}$ Department of Pharmacology \& Therapeutics, ${ }^{2}$ Department of Radiotherapy, JK Cancer Institute, ${ }^{3}$ Department of Community Medicine, GSVM Medical College, Kanpur, UP, India ${ }^{4}$ Senior Research Scientist, Clinical Pharmacology Unit, Ranbaxy Laboratories Ltd., Noida, UP, India
\end{abstract}

Received: 31 August 2013 Accepted: 14 September 2013

\section{*Correspondence to:}

Dr. Varun Sharma,

Email:

varun.sharma2003@yahoo.com; DrVarun.Sharma@ranbaxy.com

(C) 2013 Kushwaha V et al. This is an open-access article distributed under the terms of the Creative Commons Attribution NonCommercial License, which permits unrestricted noncommercial use, distribution, and reproduction in any medium, provided the original work is properly cited.

\begin{abstract}
Background: Radiotherapy has an important role in treatment of oral cancer, but it causes some deleterious effect on healthy cells. Radiation produces free radicals which cause lipo-peroxidation, alteration of protein, and DNA damage, and eventually cell death. This study is designed to evaluate protective role of antioxidants in oral malignancies treated with radiotherapy. Methods: This study is conducted in patients of oral cancer treated with radiotherapy. Patients were divided into two groups, control $(n=7)$ and test $(n=9)$. Patients in control group treated with radiotherapy alone and in test group were supplemented with oral antioxidants throughout the radiotherapy course. Pre and post radiotherapy levels of MDA, SOD and Glutathione reductase were measured in blood and cancerous tissue in both groups and statistically compared. TNM staging before and after radiotherapy and side effects of radiotherapy were also compared in both groups.

Results: On statistical comparison of mean difference values of MDA, SOD \& GR of control v/s test group, it was noticed that there was a significant reduction in MDA $(p<0.05)$ and significant increase in GR levels $(p<0.05)$ but non significant increase in SOD levels $(p>0.05)$ in test group in comparison to control group for both blood and tissue levels. TNM status of patients improved significantly after radiotherapy in test group. Comparison of side effects between both groups indicated that there was reduction in side effects in test group after radiotherapy.

Conclusion: These findings indicated the protective role of antioxidants against free radicals produced in oral malignancies treated with radiotherapy.
\end{abstract}

Keywords: Free radical scavengers, Malonyldialdehyde (MDA), Superoxide dismutase (SOD), Glutathione reductase (GR), Radiotherapy

\section{INTRODUCTION}

Incidence of cancer of oral cavity is increasing worldwide. Cancer of oral cavity is one of the most common malignancies in Indian subcontinent. Smoking, use of alcohol, smokeless tobacco products, and HPV infections are the major risk factors for oral cavity cancer, with smoking and alcohol having synergistic effects. ${ }^{1,2}$

Early cancers (stage I and stage II) of the lip and oral cavity are highly curable by surgery or by radiation therapy. ${ }^{3}$ Most patients with stage III or stage IV tumors are candidates for treatment by a combination of surgery and radiation therapy. ${ }^{4}$ So radiotherapy is the mainstay of treatment of cancers of oral cavity along with surgery.

Free radicals or reactive oxygen species (ROS) are generated during radiotherapy which besides killing the tumor cells may damage the healthy cells also. ${ }^{5}$ These ROS cause lipid-peroxidation of plasma membrane and cell organelles, inactivation of enzymes, depolymerization of polysaccharides \& DNA damage that eventually cause cell death. There are some antioxidant defence in biological systems, non-enzymatic (beta carotene; vitamins- C, E; glutathione etc.) as well as enzymatic (Superoxide dismutase SOD; catalase; 
glutathione reductase etc.) which protect the cells from damage induced by free radicals.

It is well known that Reactive Oxygen Species (ROS) mediate cytotoxic tumor activity and antioxidants mediate anticancer activity, by modifying the cellular homeostatic redox balance. Lipid peroxidation is an indicator of free radical metabolism and oxidative stress in living beings. Malonyldialdehyde (MDA) a by-product of lipid peroxidation (LPO), which inherent in carcinogenesis showed discrepancies in its serum values in radiation treated malignant cases of earlier research studies. Various study results indicates significant increase $^{6,7}$; no difference ${ }^{8}$, and significant decrease ${ }^{9}$ in lipid peroxidation or MDA levels in oral cancer patients than healthy controls.

The present study was designed to ascertain the variations in the levels of serum \& tissue MDA, a marker of oxidative stress that determines an extent of lipid peroxidation and concentration of serum \& tissue superoxide dismutase (SOD) and glutathione reductase, antioxidant enzymes that determines status of antioxidant defence of cells in patients of oral cancer treated with radiotherapy.

\section{METHODS}

The study was conducted in the Department of Pharmacology \& Therapeutics and Biochemistry Department, GSVM Medical College, Kanpur and JK Cancer \& Research Institute. Approval of institutional ethics committee was taken and study was conducted in accordance with the guidelines provided by ICMR. In the present study diagnosed cases of oral cancer attending the JK Cancer Institute for radiotherapy were selected as the study group. Study group was further subdivided into Test group \& Control group.

\section{Exclusion criteria for patients}

1. Patients who were candidates for only surgical resection.

2. Patients who required surgical resection as primary treatment and radiotherapy as an adjuvant therapy.

3. Patients who required chemotherapy and/or targeted therapy.

4. Patients who required multiple modalities (surgery/chemotherapy/targeted

therapy/radiotherapy) as treatment.

\section{Inclusion criteria for patients}

1. Patients with small tumor mass (Stage-I \& II) who were candidates for radiotherapy as sole treatment (radiotherapy was sufficient for cure).

2. Patients with large tumor mass (Stage-III \& IV) — who required radiotherapy as neo-adjuvant therapy to shrink the large tumor mass for ease of surgical resection.
3. Patients with advanced cancer who required radiotherapy as palliative therapy to relieve symptoms.

\section{Parameters to be compared}

1. Biochemical markers - Superoxide dismutase (SOD), Malonyldialdehyde (MDA) \& Glutathione reductase (GR) levels in blood and tissue (biopsy), pre and post radiotherapy in both groups.

2. TNM staging - pre \& post radiotherapy in both groups.

3. Side effects - of radiotherapy in both groups.

\section{Experimental protocol}

In control group seven diagnosed cases of oral cancer selected for radiotherapy were included and treated with radiotherapy only (without antioxidants).

In test group nine patients of oral cancer included and supplemented with a combination of oral antioxidant; multivitamin and multimineral tablets once in a day starting one week prior to radiotherapy and continued throughout the course of radiotherapy.

The patients in both groups were treated with the standard dose of radiations depending upon the grade and stage of malignancy.

The first venous blood sample was collected from the patients before initiation of radiotherapy and the second venous blood sample after completion of radiotherapy course. In same way first cancerous tissue sample taken by punch biopsy before initiating radiotherapy and the second sample was taken after radiotherapy.

Blood \& tissue samples were used for estimation of MDA, SOD \& Glutathione reductase (GR). TNM staging $\&$ side effects of radiotherapy were studied in both test $\&$ control groups.

\section{Collection of samples}

Blood sample $-5 \mathrm{ml}$ of venous blood was drawn in vial containing heparin and kept at $2^{\circ}-8^{\circ} \mathrm{C}$.

Tissue sample - A piece of cancerous tissue taken from oral growth by punch biopsy forceps, kept in vial and stored in freezer afterwards a $10 \% \mathrm{w} / \mathrm{v}$ tissue homogenate was prepared in $1.5 \%$ buffered $\mathrm{KCl}$ solution $(\mathrm{pH}=7.4)$ for the estimation of MDA, SOD \& GR.

\section{Biochemical investigations}

Assay of lipid peroxidation- Malonyldialdehyde (MDA) and assay of antioxidant enzymes- Superoxide dismutase (SOD) and Glutathione reductase (GR) was done as per standard techniques. ${ }^{10-12}$ 


\section{Statistical analysis}

Results were presented as Mean \pm SD. The statistical significance of observed difference in the parameters between the various groups was determined by the student's ' $t$ ' test. $\mathrm{P}<0.05$ was considered as significant.

\section{RESULTS}

\section{Blood \& tissue MDA levels (as marker of lipid peroxidation)}

In control group mean blood MDA level was observed to be increased after radiotherapy as compared to pre radiotherapy. The difference was noticed to be statistically significant $(\mathrm{p}<0.05)$. While in test group mean blood level of MDA was found to be significantly lowered $(\mathrm{p}<0.001)$ after radiotherapy. In tissue also mean MDA level was higher after radiotherapy in control group and difference was statistically significant $(\mathrm{p}<$ 0.05 ), while in test group mean tissue MDA level was found to be significantly lowered $(\mathrm{p}<0.05)$ after radiotherapy (Table 1).

\section{Blood \& tissue SOD \& GR levels (as markers of antioxidant activity)}

In control group blood SOD level was lowered significantly after radiotherapy as compared to the levels pre radiotherapy $(p<0.001)$, while in test group mean value was significantly raised after radiotherapy ( $\mathrm{p}<$ 0.001). In tissue also SOD level was decreased after radiotherapy as compared to pre-radiotherapy level in control group and the difference was statistically significant $(\mathrm{p}<0.05)$, while in test group post radiotherapy level was found to be significantly raised as compared to the pre radiotherapy level $(\mathrm{p}<0.05)$ (Table 1).

Table 1: Statistical comparison of levels of biochemical markers MDA, SOD \& GR in control \& test groups before and after radiotherapy.

\begin{tabular}{|lllll|}
\hline \multirow{2}{*}{ Parameter } & Control $(\mathbf{n}=7)$ & & Test $(\mathbf{n}=9)$ & \\
& Pre-radiotherapy & Post-radiotherapy & Pre-radiotherapy & Post-radiotherapy \\
\hline \hline 1. MDA in blood $(\mathrm{nmols} / \mathrm{ml})$ & $3.2 \pm 0.216$ & $3.71 \pm 0.3503^{*}$ & $3.1 \pm 0.39$ & $2.22 \pm 0.24 * * *$ \\
\hline 2. MDA in tissue $(\mathrm{nmols} / \mathrm{ml})$ & $7.26 \pm 0.489$ & $8.49 \pm 0.67^{*}$ & $7.03 \pm 0.89$ & $4.98 \pm 0.74^{*}$ \\
\hline 3. SOD in blood $(\mathrm{U} / \mathrm{gHb})$ & $301.71 \pm 7.25$ & $288.71 \pm 5.96^{* * *}$ & $296.22 \pm 11.75$ & $308.22 \pm 7.51^{* * *}$ \\
\hline 4. SOD in tissue $(\mathrm{U} / \mathrm{ml})$ & $27.82 \pm 0.64$ & $26.46 \pm 0.86^{*}$ & $27.35 \pm 1.08$ & $28.44 \pm 0.69^{*}$ \\
\hline 5. GR in blood $(\mathrm{U} / \mathrm{gHb})$ & $1.81 \pm 0.073$ & $1.61 \pm 0.065^{* *}$ & $1.76 \pm 0.24$ & $2.85 \pm 0.35^{* * *}$ \\
\hline 6. GR in tissue $(\mathrm{U} / \mathrm{ml})$ & $234.80 \pm 21.00$ & $209.25 \pm 20.80^{* * *}$ & $228.06 \pm 33.03$ & $369.92 \pm 45.13^{* *}$ \\
\hline
\end{tabular}

$* \mathrm{p}<0.05 ; \quad * * \mathrm{p}<0.01 ; * * * \mathrm{p}<0.001$

In control group post radiotherapy level of GR in blood was observed to be significantly decreased as compared to pre radiotherapy in both blood $(\mathrm{p}<0.01) \&$ tissue $(\mathrm{p}<$ $0.001)$. While in test group there was statistically significant increase level of GR after radiotherapy as compared to pre-radiotherapy in both blood $(\mathrm{p}<0.001) \&$ tissue $(\mathrm{p}<0.01)($ Table 1$)$.

On statistical comparison of mean difference values of MDA, SOD \& GR of control v/s test group, it was noticed that there was a significant reduction in MDA ( $p$ $<0.05)$ and significant increase in GR levels $(\mathrm{p}<0.05)$ but non significant increase in SOD levels $(\mathrm{p}>0.05)$ in test group in comparison to control group for both blood and tissue levels were observed.

\section{TNM staging}

It was observed that in control group after radiotherapy out of 7 patients only one patient had complete response, three had moderate, two had mild response \& one patient had no response in tumor growth but showed improvement in lymph node status (Table 2). While in test group out of 9 patients 3 had complete, 4 had moderate and 2 patients had mild improvement in tumor size \& lymph node status after radiotherapy (Table 3 ).

\section{Side effects}

Comparison of side effects between control \& test group indicated that there was reduction in side effects in test group after radiotherapy (Table $4 \& 5$ ). 
Table 2: TNM staging in control group before \& after radiotherapy.

\begin{tabular}{|lll|}
\hline $\begin{array}{l}\text { S. } \\
\text { NO. }\end{array}$ & $\begin{array}{l}\text { TNM staging } \\
\text { (pre-radiotherapy) }\end{array}$ & $\begin{array}{l}\text { TNM staging } \\
\text { (Post-radiotherapy) }\end{array}$ \\
\hline 1 & $\mathrm{~T}_{4} \mathrm{~N}_{2 \mathrm{~b}} \mathrm{M}_{\mathrm{x}}$ & $\mathrm{T}_{4} \mathrm{~N}_{0} \mathrm{M}_{\mathrm{x}}$ \\
\hline 2 & $\mathrm{~T}_{3} \mathrm{~N}_{1} \mathrm{M}_{0}$ & $\mathrm{~T}_{2} \mathrm{~N}_{0} \mathrm{M}_{0}$ \\
\hline 3 & $\mathrm{~T}_{2} \mathrm{~N}_{0} \mathrm{M}_{0}$ & $\mathrm{~T}_{0} \mathrm{~N}_{0} \mathrm{M}_{0}$ \\
\hline 4 & $\mathrm{~T}_{3} \mathrm{~N}_{0} \mathrm{M}_{\mathrm{x}}$ & $\mathrm{T}_{1} \mathrm{~N}_{0} \mathrm{M}_{\mathrm{x}}$ \\
\hline 5 & $\mathrm{~T}_{3} \mathrm{~N}_{1} \mathrm{M}_{\mathrm{x}}$ & $\mathrm{T}_{1} \mathrm{~N}_{0} \mathrm{M}_{\mathrm{x}}$ \\
\hline 6 & $\mathrm{~T}_{4} \mathrm{~N}_{1} \mathrm{M}_{0}$ & $\mathrm{~T}_{3} \mathrm{~N}_{0} \mathrm{M}_{0}$ \\
\hline 7 & $\mathrm{~T}_{3} \mathrm{~N}_{1} \mathrm{M}_{0}$ & $\mathrm{~T}_{2} \mathrm{~N}_{1} \mathrm{M}_{0}$ \\
\hline
\end{tabular}

Table 3: TNM staging in test group before \& after radiotherapy.

\begin{tabular}{|lll|}
\hline $\begin{array}{l}\text { S. } \\
\text { NO. }\end{array}$ & $\begin{array}{l}\text { TNM staging } \\
\text { (Pre-radiotherapy) }\end{array}$ & $\begin{array}{l}\text { TNM staging } \\
\text { (Post-radiotherapy) }\end{array}$ \\
\hline 1 & $\mathrm{~T}_{3} \mathrm{~N}_{0} \mathrm{M}_{\mathrm{x}}$ & $\mathrm{T}_{0} \mathrm{~N}_{0} \mathrm{M}_{\mathrm{x}}$ \\
\hline 2 & $\mathrm{~T}_{2} \mathrm{~N}_{1} \mathrm{M}_{\mathrm{x}}$ & $\mathrm{T}_{2} \mathrm{~N}_{0} \mathrm{M}_{\mathrm{x}}$ \\
\hline 3 & $\mathrm{~T}_{3 / 4} \mathrm{~N}_{0} \mathrm{M}_{0}$ & $\mathrm{~T}_{3 / 4} \mathrm{~N}_{0} \mathrm{M}_{0}$ \\
\hline 4 & $\mathrm{~T}_{3} \mathrm{~N}_{1} \mathrm{M}_{\mathrm{x}}$ & $\mathrm{T}_{1} \mathrm{~N}_{1} \mathrm{M}_{\mathrm{x}}$ \\
\hline 5 & $\mathrm{~T}_{3} \mathrm{~N}_{0} \mathrm{M}_{0}$ & $\mathrm{~T}_{0} \mathrm{~N}_{0} \mathrm{M}_{0}$ \\
\hline 6 & $\mathrm{~T}_{2} \mathrm{~N}_{0} \mathrm{M}_{0}$ & $\mathrm{~T}_{1} \mathrm{~N}_{0} \mathrm{M}_{0}$ \\
\hline 7 & $\mathrm{~T}_{4} \mathrm{~N}_{2 \mathrm{a}} \mathrm{M}_{\mathrm{x}}$ & $\mathrm{T}_{1} \mathrm{~N}_{1} \mathrm{M}_{\mathrm{x}}$ \\
\hline 8 & $\mathrm{~T}_{4} \mathrm{~N}_{0} \mathrm{M}_{\mathrm{x}}$ & $\mathrm{T}_{3 / 4} \mathrm{~N}_{0} \mathrm{M}_{\mathrm{x}}$ \\
\hline 9 & $\mathrm{~T}_{2} \mathrm{~N}_{1} \mathrm{M}_{0}$ & $\mathrm{~T}_{0} \mathrm{~N}_{0} \mathrm{M}_{0}$ \\
\hline
\end{tabular}

Table 4: Side effects after radiotherapy in control group.

\begin{tabular}{|c|c|c|c|c|c|c|c|c|}
\hline S. NO. & $\begin{array}{l}\text { Dryness of } \\
\text { mouth }\end{array}$ & $\begin{array}{l}\text { Loss of } \\
\text { taste }\end{array}$ & Mucositis & $\begin{array}{l}\text { Loss of } \\
\text { beard/ } \\
\text { hairs }\end{array}$ & $\begin{array}{l}\text { Loss of } \\
\text { appetite }\end{array}$ & $\begin{array}{l}\text { Pain in } \\
\text { throat }\end{array}$ & Dysphagia & $\begin{array}{l}\text { Skin } \\
\text { reaction }\end{array}$ \\
\hline 1 & + & + & + & + & & & & \\
\hline 2 & + & + & + & & & & & \\
\hline 3 & + & + & & + & & & & \\
\hline 4 & + & + & + & & & & & \\
\hline 5 & + & + & & + & & & & \\
\hline 6 & & + & + & + & & & & \\
\hline 7 & + & + & + & & & & & \\
\hline
\end{tabular}

Table 5: Side effects in test group after radiotherapy.

\begin{tabular}{|c|c|c|c|c|c|c|c|c|}
\hline S. NO. & $\begin{array}{l}\text { Dryness } \\
\text { of mouth }\end{array}$ & $\begin{array}{l}\text { Loss of } \\
\text { taste }\end{array}$ & Mucositis & $\begin{array}{l}\text { Loss of } \\
\text { beard/ } \\
\text { hairs }\end{array}$ & $\begin{array}{l}\text { Loss of } \\
\text { appetite }\end{array}$ & $\begin{array}{l}\text { Pain in } \\
\text { throat }\end{array}$ & Dysphagia & $\begin{array}{l}\text { Skin } \\
\text { reaction }\end{array}$ \\
\hline 1 & + & & \pm & & & & & \\
\hline 2 & + & & & & & & & + \\
\hline 3 & + & + & + & & & & & \\
\hline 4 & + & & & & & + & & \\
\hline 5 & & & + & & & & + & \\
\hline 6 & & & + & + & & & + & \\
\hline 7 & + & & + & & & & & \\
\hline 8 & + & & \pm & & & & & \\
\hline 9 & + & + & & & & & & \\
\hline
\end{tabular}




\section{DISCUSSION}

The role of free radicals in cancer \& radiation injury has been extensively studied. Major therapeutic effect of radiation is due to free radical production. ${ }^{13}$ Radiation and chemotherapy, damage both healthy and malignant cells by oxidative process i.e. by generation of free radicals. ${ }^{14}$ Cancer cells do not absorb antioxidants as efficiently as healthy cells. It may be possible to support normal tissue with antioxidants while making the oxidative process selectively toxic to malignant cells. ${ }^{15}$

The idea of using antioxidants in patients of oral cancer treated with radiotherapy emerged from previous studies showing that use of antioxidants supports the normal cells and makes the malignant cells more vulnerable to radiation induced oxidative damage and reduce the toxic $\&$ side effects of radiotherapy on normal tissue. Although a few negative studies had also been reported showing decrease in therapeutic efficacy of radiotherapy due to use of antioxidants in treatment of malignancies.

Antioxidant nutrients and precursors such as vitamin A, $\mathrm{C}$ and $\mathrm{E}$, selenium, copper, zinc and $\mathrm{N}$-acetyl cysteine may offer protection to healthy cells against oxidative injury by antineoplastic therapy. ${ }^{16}$

There are various methods for detection of generation of free radicals; one such method is to study the indicators of oxidative stress such as MDA and antioxidant defence such as SOD \& glutathione reductase. Theoretically, MDA should increase while the other two should decrease following free radical generation.

This study was carried out to observe the effect of radiotherapy and then the effect of antioxidant with radiotherapy on levels of MDA, SOD and Glutathione reductase in blood as well as tissue alongwith TNM staging and side effects.

\section{Parameters in blood and tissue}

After radiotherapy blood level of MDA, which was used as the parameter of oxidative stress was found to be significantly elevated in control group as compared to pre-radiotherapy level. This signifies that radiation leads to generation of free radicals, free radicals reacts with unsaturated lipids of cell membrane, a phenomenon known as membrane lipid peroxidation (MLP) to produce highly cytotoxic endoperoxides, MDA is an intermediate product of MLP and an increase in its level denotes enhanced generation by free radicals. Similar findings were reported by Sabitha et al $(1999)^{17} \&$ P. Sangeetha et al $(1990)^{18}$ who reported that levels of MDA showed a significant increase in oral cancer patients untreated \& treated with radiotherapy.

The level of MDA in blood, in test group (treated with antioxidants) was found to be significantly decreased after radiotherapy as compared to pre-radiotherapy levels. That means antioxidants given to the patient react with free radicals (reactive oxygen species; ROS) generated by radiotherapy and convert them into non reactive state and decreases the lipid peroxidation, in other terms suppress the oxidative stress. ${ }^{19}$ A similar study by Wedleigh showed that vitamin $\mathrm{E} \& \mathrm{C}$ along with glutathione act on cellular level by protecting cell membrane and prevent lipid peroxidation which in turn indicate that MDA value decreases due to intake of antioxidant by the patient. ${ }^{20}$

In the present study the blood levels of SOD, which was used as parameter for antioxidant defence was found to be significantly decreased in control group after radiotherapy as compared to before radiotherapy. This indicates that endogenous antioxidants consumed during the process of scavenging the ROS. These findings were in accordance with findings of Sabitha et al (1999) ${ }^{17} \&$ P. Sangeetha et al (1990). ${ }^{18}$

The level of SOD in blood in test group was found to be significantly increased after radiotherapy as compared to pre-radiotherapy level. This indicates that antioxidant was successful in preventing consumption of SOD by free radicals, by decreasing production of free radicals and/or scavenging them. This finding was in accordance with the findings of Nagler et al. ${ }^{21}$

In the present study level of glutathione reductase, which serves as another parameter for antioxidant defence showed significant decrease in control group after radiotherapy as compared to before radiotherapy. These findings were in accordance with the findings of Sabitha et al (1999). ${ }^{17}$ However the level of glutathione reductase in test group was significantly increases after radiotherapy as compared to pre-radiotherapy. This indicates that antioxidant was successful in preventing consumption/suppression of SOD by free radicals, by decreasing production of free radicals and/or by scavenging them. This finding was in accordance with findings of Henneken (1984) ${ }^{22}$ \& Machlin et al (1987). ${ }^{23}$

In present study we also found that tissue levels of MDA, SOD \& Glutathione reductase was also altered in similar way as in blood levels.

\section{Other parameters}

In present study on comparison of TNM staging between control \& test group we found that reduction of tumor size due to radiotherapy was more in test group $(77.7 \%$ responded well; 22.3\% responded poorly or not at all) than control group $(57.9 \%$ patients had responded well and $42.1 \%$ had none or poor response). ${ }^{21,24,25}$ Tumour size and stage are significant predictors of overall and disease-free survival for patients with oral malignancies. ${ }^{26-28}$ So, indirectly our results indicates towards better survival of antioxidant and radiotherapy treated patients than patients treated with radiotherapy only. On comparison to side effect between control \& test group there was reduction in 
the side effects in test group after radiotherapy. ${ }^{20,24,29}$ The results of our study have provided strong evidence that antioxidants can decrease free radical production due to effect of radiation and can also enhance antioxidant status of body. Antioxidant supplementation in patients receiving radiotherapy may prolong the survival time and it may increase tolerability to therapy.

\section{CONCLUSION}

It is evident from the present study that free radical scavenger significantly reduces the oxidative stress in patients of oral cancer after radiotherapy by limiting lipid peroxidation and/or scavenging reactive oxygen species generated due to irradiation. When antioxidants used in combination with radiotherapy in oral malignancies as treatment it not only contributes to favourable outcome and better survival but it also decrease propensity of side effects and toxicities of radiotherapy and increase its tolerability in cancer patients.

\section{ACKNOWLEDGEMENTS}

Authors are grateful to Mr. Ajay Kumar, Head, Department of Biochemistry, GSVM Medical College, Kanpur, India for providing laboratory support for this study.

Funding: No funding sources Conflict of interest: None declared

Ethical approval: The study was approved by the institutional ethical committee

\section{REFERENCE}

1. Blot WJ, McLaughlin JK, Winn DM, Austin DF, Greenberg RS, Preston-Martin S et al. Smoking and drinking in relation to oral and pharyngeal cancer. Cancer Res. 1988 Jun 1; 48(11):3282-7.

2. Hashibe M, Brennan P, Chuang SC, et al. Interaction between tobacco and alcohol use and the risk of head and neck cancer: pooled analysis in the International Head and Neck Cancer Epidemiology Consortium. Cancer Epidemiol Biomarkers Prev 2009; 18:541-50.

3. Cummings CW, Fredrickson JM, Harker LA, et al. Otolaryngology - Head and Neck Surgery. Saint Louis, Mo: Mosby-Year Book, Inc, 1998.

4. Harrison LB, Sessions RB, Hong WK, eds.: Head and Neck Cancer: A Multidisciplinary Approach. Philadelphia, Pa: Lippincott-Raven, 1999.

5. Anderson TJ, Meredith IT, Yeung AC, Frei B, Selwyn AP, Ganz P. The effect of cholesterollowering and antioxidant therapy on endotheliumdependent coronary vasomotion. N Engl J Med. 1995 Feb 23; 332(8):488-93.

6. Sabitha KE, Shyamaladevi CS. Oxidant and antioxidant activity changes in patients with oral cancer and treated with radiotherapy. Oral Oncol 1999 May; 35(3):273-7.
7. Manoharan S, Kolanjiappan K, Suresh K, Panjamurthy K. Lipid peroxidation \& antioxidants status in patients with oral squamous cell carcinoma. Indian J Med Res. 2005 Dec;122(6):529-34.

8. Subapriya R, Kumaraguruparan R, Ramachandran CR, Nagini S. Oxidant -Antioxidant status in patients with oral squamous cell carcinoma at different oral sites. Clin Biochem 2002; 35:489-93.

9. Upadhya S, Upadhya S, Krishna Mohan S. Oxidant - Antioxidant Status in colorectal cancer patients before and after treatment. Ind $\mathrm{J}$ Clin Biochem 2004; 19: 80-83.

10. Ohkawa H, Ohishi N \& Yagi K. Assay for lipid peroxidase in animal tissue by thio-barbituric acid reaction. Anal Biochem 1979; 95:357-8.

11. Wooliams JA, Wiener G, Anderson PH, Mc Murray CH. Research veterinary science.1983; 34: 253-256.

12. Goldberg DM \& Sponser RJ. In methods of enzymatic analysis (Bergmeyen H.V. Ed) $3^{\text {rd }}$ ed: Verlog Chemie Deer field Beach, F.I. 1983; Vol.3, pp 258-265.

13. Chapman JD, Reuvers AP. The time scale of radioprotection in mammalian cells. Experientia Suppl. 1977; 27:9-18.

14. Quillen P. Adjuvant nutrition in cancer treatment. Am J Nat Med 1995; 2(5):8-14.

15. Demling RD. Glutamine and antioxidant replacement therapy after severe burn and trauma monograph. 1996

16. Goringe AP, Brown S, O'Callaghan U, Rees J, Jebb $\mathrm{S}$, Elia $\mathrm{M}$ et al. Glutamine and vitamin $\mathrm{E}$ in the treatment of hepatic veno-occlusive disease following high dose chemotherapy. Bone Marrow Transplant 1998 Apr;21(8):829-32

17. Sabitha KE, Shyamaladevi CS. Oxidant and antioxidant activity changes in patient with oral cancer and treated with radiotherapy.Oral Oncol. 1999 May;35(3):273-7.

18. Sangeetha P, Das UN, Koratkar R, Suryaprabha P. Increase in free radical generation and lipid peroxidation following chemotherapy in patients with cancer. Free Radic Biol Med. 1990;8(1):15-9.

19. Anissa K Shariff, Sangita R Patil, Pramod S Shukla, Ajit V Sontakke, Anup S Hendre and Anand K Gudur. Effect of oral antioxidant supplementation on lipid peroxidation during radiotherapy in head and neck malignancies. Indian Journal of Clinical Biochemistry 2009; 24(3):307-11.

20. Wadleigh RG, Redman RS, Graham ML, Krasnow $\mathrm{SH}$, Anderson A, Cohen MH. Vitamin E in the chemotherapy induced oral mucositis. Am J Med. 1992 May;92(5):481-4.

21. Nagler RM, Reznick AZ, Slavin S, Nagler A. Partial protection of rat parotid glands from irradiationinduced hyposalivation by manganese superoxide dismutase. Arch Oral Biol. 2000 Sep;45(9):741-7.

22. Hennekens $\mathrm{CH}$. Micronutrients and cancer prevention. Cancer Det Prev 1984;7:147-58. 
23. Machlin LJ, Bendich A. Free radical tissue damage: protective role of antioxidant nutrients. FASEB J. 1987 Dec;1(6):441-5.

24. Lamson DW, Brignall MS. Antioxidant in cancer therapy: their actions and interactions with oncologic therapies. Altern Med Rev. 1999 Oct;4(5): 304-29.

25. JM Jamison, HS Taper, J Gilloteaux, JL Summers. The in vivo anti-tumor activity of vitamin $\mathrm{C}, \mathrm{K}_{3}$ combinations against human prostate cancer correlates with their abilities to reactivate $\mathrm{ON}$ ases. Presented at the sixth international symposium on predictive oncology and intervention strategies, Paris, $10^{\text {th }}$ feb. 2002.

26. R. Bryan Bell, Deepak Kademani, Louis Homer, Eric J. Dierks, Bryce E. Potter. Tongue Cancer: Is There a Difference in Survival Compared With Other
Subsites in the Oral Cavity? Journal of Oral and Maxillofacial Surgery. 2007 February; 65(2): 229-36.

27. S. R. Larsen, J. Johansen, J. A. Sørensen, A. Krogdahl. The prognostic significance of histological features in oral squamous cell carcinoma. Journal of Oral Pathology \& Medicine. 2009 September; 38(8): 657-62.

28. Brouha XDR, Tromp DM, Hordijk G, Winnubst JAM, de Leeuw RJ. Oral and pharyngeal cancer: analysis of patient delay at different tumor stages. Head Neck 2005;27:939-45.

29. Blumenthal RD, Lew W, Reising A, Soyne D, Osorio $\mathrm{L}$, Ying $\mathrm{Z}$ et al. Anti-oxidant vitamin reduces normal tissue toxicity induced by radio-immunotherapy. Int $\mathrm{J}$ Cancer. 2000 Apr 15;86(2): 276-80.

doi:10.5455/2319-2003.ijbcp20131212

Cite this article as: Kushwaha V, Sahani K, Sharma V, Saeed S, Barman SK. Role of free radical scavengers in oral malignancies treated with radiotherapy. Int J Basic Clin Pharmacol 2013;2:73541. 